\title{
Cotinine Measurement
}

National Cancer Institute

\section{Source}

National Cancer Institute. Cotinine Measurement. NCI Thesaurus. Code C92249.

The determination of the amount of cotinine present in a sample. 